\title{
Understanding the role of spring grazing of lucerne in the Central Otago environment
}

\author{
D.R. STEVENS ${ }^{1}$, B.R. THOMPSON ${ }^{1}$, A. CARRUTHERS ${ }^{2}$, A.J. WALL ${ }^{1}$, M.J. CASEY ${ }^{3}$, \\ R. PHISKIE ${ }^{3}$, P. YOUNG ${ }^{4}$ and D.J. MOOT $^{5}$ \\ ${ }^{1}$ AgResearch Invermay, Private Bag 50034, Mosgiel \\ ${ }^{2}$ Combined Rural Traders, Dunedin \\ ${ }^{3} P G G$ Wrightson, Private Bag, Dunedin \\ ${ }^{4}$ Farm Advisory Services, Alexandra \\ ${ }^{5}$ Lincoln University \\ david.stevens@agresearch.co.nz
}

\begin{abstract}
The Lucerne for Lambs Sustainable Farming Fund project used on-farm data and whole-farm modelling to help farmers understand the impact of increasing the amount of grazing dryland lucerne on Central Otago farms. On-farm results from 2 years showed that spring stocking rate on lucerne-based pasture averaged 10 ewes and their lambs per hectare compared with 3 ewes and their lambs on dryland grass-based pasture. Lamb growth rate was approximately $50 \mathrm{~g}$ /day higher on lucerne-based pastures, resulting in a total lamb production of $358 \mathrm{~kg}$ liveweight/ha at weaning compared with $108 \mathrm{~kg}$ liveweight/ha on grass-based pastures. Whole-farm modelling showed that increased profitability could be achieved by the addition of significant areas of grazing lucerne. Profitability increased by $\$ 119 /$ ha on a 5000 ha traditional merino property. Profitability of a 522 ha partially irrigated valley floor property running crossbred ewes was increased by $\$ 249 /$ ha. Using lucerne for spring grazing also reduced the impacts of both winter and summer droughts in the variable conditions of Central Otago.

Keywords: dryland, lamb growth, lucerne, modelling, profitability, stocking rate, whole farm systems.
\end{abstract}

\section{Introduction}

The Central Otago region of the South Island is the driest $\left(300-400 \mathrm{~mm}\right.$ rainfall), coldest $\left(-28^{\circ} \mathrm{C}\right.$, lowest recorded) and hottest $\left(+35^{\circ} \mathrm{C}\right.$, highest recorded) region of New Zealand (Cossens 1987). As such it provides a hostile environment for farming with dry summers and long cold winters (120 days with little or no growth). The geology of the region includes broad intermontane basins between block uplift mountains (Brash \& Beecroft 1987). The mountain regions have higher rainfall, increasing with altitude, but shorter growing seasons, restricted by temperature and snowfall.

Lucerne is used in these systems in several ways. Basal soils of the valley floor have a natural $\mathrm{pH}$ of 6-7
(Brash \& Beecroft 1987). Often lucerne is used on soils with low soil moisture holding capacity to maximise the production of these areas of the farm. Soils with greater soil moisture holding capacity are used for pasture, and are more likely to be irrigated. In these cases the lucerne will be used for conservation to provide one or two cuts per annum to help fill the significant winter feed deficit (Kelly 1987). These areas of lucerne may also be used for lamb finishing during the autumn if summer rainfall allows regrowth. This traditional use of lucerne in Central Otago has relegated it to a forage crop for hay making, with occasional grazing. This has restricted its use and may prevent the potential of sheep grazing systems to be fully revealed in this environment.

Recent developments of our understanding of the growth pattern of lucerne, responses to defoliation and interactions with root reserves have created new rules and grazing opportunities (Moot et al. 2003). An increase in the understanding of the water use efficiency (Brown et al. 2005a,b) and interactions with nitrogen (Moot et al. 2008) has enabled more accurate prediction of the responses of various forages to available soil water. This has increased the ability to predict responses and develop high performing lucerne grazing systems (Avery et al. 2008; Kearney et al. 2010).

The Lucerne for Lambs project aimed to apply this new information in a grazing programme. Specifically, the first stage was to mentor farmers on the practical aspects of grazing lucerne through individual farm visits and discussion with science experts. This support gave the farmers confidence to undertake a change from their traditional management systems. The second stage used their results from on-farm grazing to quantify how lucerne grazing could improve on-farm profitability within the wider region. To do this the teach-and-visit approach upskilled farmers and local agribusiness personnel. Progress of individual farmers then provided the demonstration of success and testimonials as they 
shared their knowledge formally and informally with the wider farming community. This paper documents the data collected on farm and the consequent farm modelling from that data used to investigate the changes required to make the grazing of lucerne a significant and profitable part of farming in the Central Otago region.

\section{Materials and Methods}

\section{A. On-farm demonstrations}

On-farm comparisons of lactating ewes grazing grassbased pasture or lucerne-based swards were made during the springs of 2009 and 2010. In 2009, data from three farms were recorded, while data from six farms were recorded in 2010. The farm types and farm systems employed were diverse, which provided a wide range of test conditions for lucerne. These farms were in the Maniototo, Ida, and Upper Clutha valleys. They had dryland pasture, irrigated pasture, lucerne/grass mixes and lucerne alone. Ewes were Merino, crossbred, Corriedale and Polwarth, with some terminal sires being used. The farms ranged in size from the typical valley floor property (approximately $400 \mathrm{ha}$ ) with some irrigation, to extensive runs (over 5000 ha). Average annual rainfall varied from 350 to $600 \mathrm{~mm}$ across the sites.

Each farm monitored at least 100 ewes and their lambs grazing either lucerne or perennial pasture during the spring and early summer. Ewes were weighed and condition scored at docking, and then at weaning (2010 only), while lambs were weighed at docking (approximately 4 weeks of age) and weaning (approximately 12 weeks of age) in both years. The area used by each mob was recorded and stocking rate calculated from this. Grazing of the lucerne began at about docking time. The initial stocking rate on the lucerne was determined by calculating the approximate lucerne growth rate based on historic records of soil moisture and air temperature at nearby climate recording stations, associated with soil depth and water holding capacity information. Temperature relationships were based on Moot et al. (2003) while the soil water use efficiency relationships of Brown et al. (2005b) were used. A minimum of six paddocks was used within the lucerne rotations, with a calculated regrowth period of at least 35 days between grazing events. Residual grazing height was determined by a field test of stem tensile strength as an indicator of stem lignification and therefore feed quality. This was done by taking a lucerne stem (to ground level) and pulling the tip down vertically until the stem broke. In the early spring stems were generally pliant and did not break, while later in spring as the lucerne stems matured, breaking occurred $1-5 \mathrm{~cm}$ above the base of the stem. Salt, supplementary fibre (as hay, baleage or rough pasture) and water were made available to ewes and lambs grazing lucerne. Grazing plans for the perennial pasture were determined by the farmer and pastures were usually continuously grazed. Animal health was monitored regularly to ensure that issues were identified early and any problems solved as required.

\section{B. Assessing the impacts at a whole farm scale}

Farmax ${ }^{\circledR}$ was used to model two farming scenarios typical of the Central Otago region to investigate the potential of increasing the area sown in lucerne (Stevens \& Thompson 2012). Data from the on-farm demonstrations along with calculated lucerne growth rates was used. Economic analyses included all cropping and lucerne development costs, as well as onfarm variable costs associated with production, but not standing charges, capital costs or wages of management. Increases in breeding stock were done using natural increases, rather than purchase. The modelling of the properties was done over a 7-year period to allow the full effect of the changes to be expressed.

\section{Scenario 1: Traditional merino hill}

This scenario was based on large scale farms, averaging 4800 ha for half-bred and 5500 ha for merino flocks (Ibbotson Cooney Ltd 2011). Land classes included valley floor running into hills and mountains that provide a stratified grazing system of winter, spring/ autumn and summer country depending on altitude and snow risk. Stocking rate was low (1-3 stock units /ha) with stock being moved between different parts of the farm depending on season and feed supply. These farms are typically fine wool (half-bred and merino) flocks with low lambing percentage $(80-100 \%)$. Lambs are often taken through the winter and sold as rising oneyear-olds.

The model (1) investigated the process and implications of sowing $70 \%$ of the dryland valley floor, representing $13 \%$ of the total farm area, into lucerne over a 7-year period. Data for the model are based on actual farm data in the Ida Valley, Central Otago.

\section{Scenario 2: Intensive semi-irrigated valley floor}

This scenario was based on semi-irrigated valley basin farms of low (4 stock units (su)/ha) to medium (10 su/ ha) intensity. The stocking rate generally depends on the amount and reliability of irrigation water supply. Farm size averages 680 ha, with ewe flock size of 2500 to 5000 (Ibbotson Cooney Ltd 2011). These flocks are commonly crossbred (coarse wool Romney-based) or half-bred (merino $\times$ crossbred) genetics with the aim of producing a high lambing percentage (130-150\%) and finishing lambs where possible. This system suffers 
from the potential for a dry late spring period where both rainfall and irrigation water may be limited. This results in lamb finishing in some years but selling store stock in others.

The modelling investigated the process and implications involved with converting $75 \%$ of the dryland component (representing $29 \%$ of the farm) of a valley floor farm system into lucerne over a 6-year pasture renewal programme. The use of lucerne by the addition of extra sheep (2a) or beef cattle (2b) was compared.

\section{Testing on-farm resilience}

The resilience of both the original and lucerne farming systems to winter drought, summer drought and above average rainfall were tested in the valley floor model. Pasture growth rates were taken from recorded data in the Poolburn region (Cossens 1990) with the summer drought occurring in the 1975/76 season and the winter drought in the 1970/71 season. Predicted lucerne growth rate was calculated, taking into account the climatic conditions that occurred during the above seasons as predicted using the climatic data from the NIWA Virtual Climate Network (2012) (Station 14216).

A cost-benefit analysis was carried out for the above models. These models were based on an actual valley floor farm in the Maniototo Valley, Central Otago.

\section{Results}

\section{A. On-farm demonstrations}

Stocking rates were lowest on dryland pasture (3 ewes/ ha), increased to 5.1 ewes/ha on the lucerne/grass mixtures, and to 10 ewes/ha on both the lucerne and irrigated pasture (Table 1).

The dryland pasture stocking rates were reduced in 2010 compared with 2009 for two reasons. The dry cool late spring meant that some pastures were destocked at this time in preference to grazing on lucerne/grass mixtures, and the introduction of lucerne aided in the ability to lower the stocking rate on the dryland pasture.

The liveweight gain of the lambs was similar on dryland pasture and lucerne-grass mixtures, but approximately $50 \mathrm{~g} / \mathrm{head} / \mathrm{day}$ greater on lucerne and irrigated pasture.

The dryland pastures averaged $108 \mathrm{~kg}$ lamb weaned per hectare over the two years. The productivity on the lucerne-grass mixtures was approximately twice that at $204 \mathrm{~kg} / \mathrm{ha}$, while that on lucerne was $358 \mathrm{~kg} / \mathrm{ha}$. The irrigated pasture was $525 \mathrm{~kg} / \mathrm{ha}$ in the one year that it was recorded. Weaning date was later by 12 to 28 days in 2010 due to greater winter and spring rainfall, but data in Table 1 have been adjusted to reflect this.

Ewes on lucerne had both a higher liveweight and body condition score (BCS), and had a lower proportion below a BCS of 2 than their counterparts on dryland

Table 1. The comparative performance of ewes and lambs grazing dryland or irrigated pasture or pure lucerne or lucerne-grass mixtures during the spring of 2009 and 2010 in Central Otago. Data for 2009 was the mean of three farms and 2010 the mean of six farms.

\begin{tabular}{|c|c|c|c|c|c|}
\hline & \multicolumn{4}{|c|}{ Forage type } & \multirow[b]{2}{*}{ Tailing \% } \\
\hline & Dryland pasture & Irrigated pasture & $\begin{array}{l}\text { Lucerne- Grass } \\
\text { mixture }\end{array}$ & Lucerne & \\
\hline \multicolumn{6}{|l|}{ Ewe stocking rate (ewes/ha) } \\
\hline 2009 & 3.5 & nd & 4.2 & 9.4 & 117.7 \\
\hline 2010 & 2.6 & 10 & 6.1 & 10.6 & 120.6 \\
\hline \multicolumn{6}{|l|}{ Lamb growth rate (g/day) } \\
\hline 2009 & 275 & nd & 266 & 330 & \\
\hline 2010 & 253 & 312 & 259 & 292 & \\
\hline \multicolumn{6}{|l|}{ Lamb production (kg live weight/ha) } \\
\hline 2009 & 135 & nd & 169 & 314 & \\
\hline 2010 & 81 & 525 & 239 & 403 & \\
\hline \multicolumn{6}{|c|}{ Ewe live weight and condition score at weaning (2010 only) } \\
\hline Liveweight (kg) & 55.4 & & & 58 & \\
\hline Condition score (BCS) & 2.9 & & & 3.15 & \\
\hline Proportion (\%) BCS<2 & 16 & & & 7 & \\
\hline
\end{tabular}


pasture (Table 1).

\section{B. Assessing the impacts at a whole farm scale}

A summary of results is presented here to highlight significant differences in productivity, profitability and resilience. The conversion of a significant area of each farm type to lucerne required a process of 7 years to stabilise stock numbers and feed inventories. Farm income was reduced in the first 1 to 3 years of the development because natural increases in stock numbers were used, which reduced the number of lambs for sale. Results of the farms before and after the conversion are presented in Table 2. Of note are the increases in stocking rate in both the traditional merino hill and valley floor models.

Cropping and supplements were a significant part of both farm systems, being $10 \%$ of the traditional merino hill (1) and $25 \%$ of the valley floor (2) base scenarios. The amount of crop and supplements were not reduced during the conversion period as it was necessary to keep the crops at a high proportion of the total farm area to feed the stock during winter. However, crop area per stock unit did decrease as stock numbers increased over the 6-year period. This was due to the ability to carry autumn lucerne growth into early winter for grazing prior to spelling in late winter.

\section{Scenario 1: Traditional merino hill}

The stock performance of the traditional merino hill model (1) was increased in line with the on-farm demonstration results. Increases in ewe liveweight $(8.1 \mathrm{~kg})$, scanning percentage $(11 \%)$, lambing percentage $(23 \%)$ and lamb weaning weight $(8.6 \mathrm{~kg})$ were modelled. There was also a significant increase in the number of lambs sold prime. Total sheep sold increased by $56 \%$, and the amount of wool sold increased by $47 \%$ (Table 2). Cattle numbers were kept the same throughout, with 139 cattle being sold each year. Lambing date was shifted from 1 October to 10 October to accommodate the extra feed demand of the increased ewe performance, coupled with the slightly later grazing requirement of the lucerne.

The traditional merino hill property increased both stocking rate and per head performance by converting $13 \%$ of the farm to grazing lucerne (representing $70 \%$ of the unimproved flats). Profit per hectare increased by $54 \%$ or $\$ 119 /$ ha.

\section{Scenario 2: Intensive semi-irrigated valley floor}

Trading cattle numbers in the valley floor model (2a) were adjusted during the conversion period to ensure that pasture covers remained at a sustainable level depending on the size of sheep number increases. A significant surplus occurred during years 3 and 4 as the natural increase in sheep numbers could not keep pace with the increase in feed supply provided by the lucerne. This is when cattle numbers were at their highest, as a result of purchasing extra R1 steers in March to be sold

Table 2. The modelled impacts of added lucerne grazing to traditional merino property and a partially irrigated valley floor property in Central Otago

\begin{tabular}{|c|c|c|c|c|c|}
\hline & \multicolumn{2}{|c|}{ Traditional merino } & \multicolumn{3}{|c|}{ Valley floor crossbred } \\
\hline & \multirow[t]{2}{*}{ Pre-development } & \multirow[t]{2}{*}{ (1) Post-development } & \multirow[t]{2}{*}{ Pre-development } & \multicolumn{2}{|c|}{ (2a) Post-development (2b) Post-development } \\
\hline & & & & Sheep & Beef \\
\hline Area (ha) & 4974 & 4974 & 522 & 522 & 522 \\
\hline Lucerne area (ha) & 104 & 774 & 80 & 230 & 230 \\
\hline Stock Units & 2.5 & 3.3 & 10.7 & 12.3 & 12.5 \\
\hline Sheep:Cattle & $88: 12$ & $91: 9$ & $77: 23$ & $81: 19$ & $69: 31$ \\
\hline Crop area (ha) & 110 & 110 & 84 & 84 & 84 \\
\hline Supplement made (ha) & 72 & $72+80$ & 60 & 60 & 60 \\
\hline Sheep wintered & 15030 & 18240 & 4155 & 4975 & 4155 \\
\hline Cattle wintered & 271 & 271 & 110 & 130 & 250 \\
\hline Total sheep sold & 7370 & 11530 & 4630 & 5560 & 4630 \\
\hline Wool (kg) & 60050 & 88190 & 16500 & 19160 & 16500 \\
\hline Revenue $(\$ 000)$ & 1,398 & 2,046 & 642 & 776 & 729 \\
\hline Variable Costs $(\$ 000)$ & 298 & 352 & 124 & 128 & 124 \\
\hline Gross Margin (\$/ha) & 220 & 339 & 993 & 1242 & 1159 \\
\hline
\end{tabular}




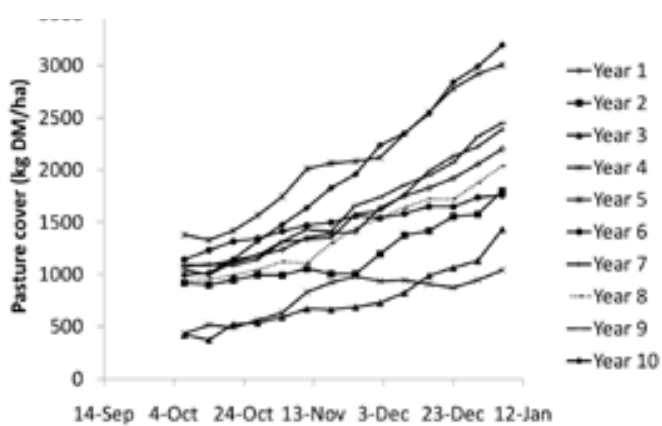

Figure 1. Calculated change in net pasture cover of lucerne when grazed with 10 ewes plus twin lambs from the 7 October during 10 spring seasons using climatic data from 2001 to 2010 for Lauder, Central Otago. Lucerne growth rates are predicted using air temperature. Target opening lucerne cover is 1000 to $1200 \mathrm{~kg} \mathrm{DM} / \mathrm{ha}$.

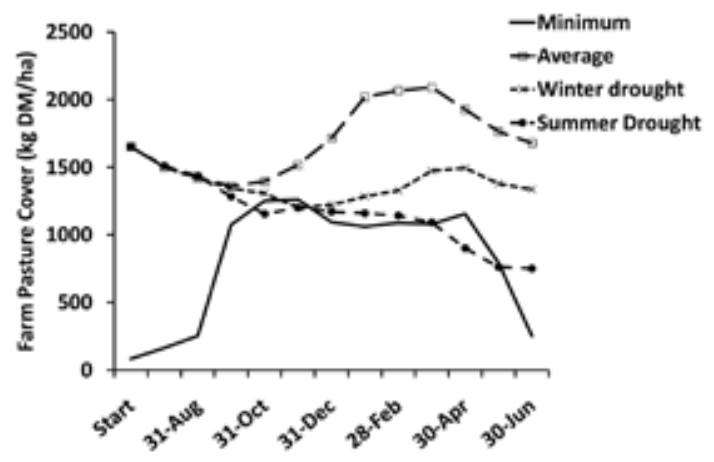

Figure 3. Predicted farm cover post lucerne development for four environmental patterns overlaid on the minimum farm cover requirements to meet animal feed demands for the Valley Floor scenario. Feed shortfalls occur when the dotted lines are below the solid line.

the following spring.

Increasing the number of cattle in the valley floor model (2b) (Table 2) while maintaining the sheep numbers at the base model level provided a profitability increase. The increase in cattle in this model was achieved using the same buying and selling policies as in the base model but with increasing numbers. All performance parameters remained the same as in the other models for the valley floor scenario.

A valley floor property running a crossbred flock also increased stocking rate when $29 \%$ of the farm, representing $75 \%$ of the dryland component of the farm, was converted to grazing lucerne. The on-farm data collected did not suggest that an increase in already high per head performance was warranted. Profitability on the valley floor property increased by $25 \%$ or $\$ 249 /$ ha.

\section{Testing on-farm resilience}

Further investigation into the variability of lucerne in the farm system was done by modelling the growth of

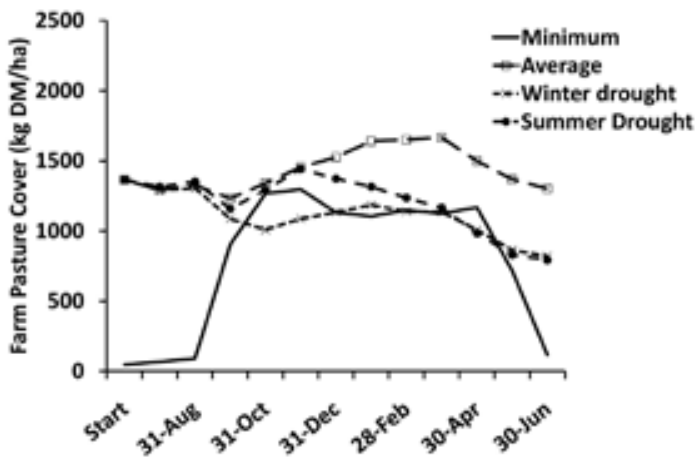

Figure 2. Predicted farm cover prior to lucerne development for four environmental patterns overlaid on the minimum farm cover requirements to meet animal feed demands for the Valley Floor scenario. Feed shortfalls occur when the dotted lines are below the solid line.

lucerne in 10 successive climate years from 2001 to 2010. That growth was compared with the lactation feed requirements of 10 ewes plus twin lambs (growing at $300 \mathrm{~g}$ /day) during spring. The pasture cover on 7 October was used as a reference point and the net accumulation of lucerne is represented after meeting the calculated feed requirements (Fig. 1). The net herbage accumulation on the lucerne pasture increased in every season, regardless of opening covers. Within the 10 years there were 2 years ( $\mathrm{Yr} 3$ and 4 ) that had opening covers well below the recommended starting cover, 6 years that had an opening cover in the recommended range of 1000 to $1200 \mathrm{~kg} \mathrm{DM}$, and 2 years (Yr 5 and 6) when the cover was above the recommended opening cover.

The resilience of the current farm system was compared with that of the lucerne system for the valley floor model (2). The average pasture growth curves prior to lucerne development were compared with growth curves that represented a winter drought, summer drought and a high rainfall year. The resulting pasture covers are represented in Fig. 2. No changes to stocking policy or feed demand have been made. This allows the extent of the potential problems to be graphically represented.

Winter drought had the greatest impact on the feed supply before conversion to lucerne. A significant feed deficit developed as the animals came off crop and continued throughout the year. Summer drought reduced cover during February and March.

The same seasons are represented after the inclusion of lucerne in Fig. 3, using calculated lucerne growth rates from the weather records of those years chosen. Of note is the lower impact of winter drought on the pasture cover on the farm, suggesting that the lucerne system will be more robust, as the important spring water use efficiency of lucerne is higher than pasture. 
The early spring cover in the summer drought scenario is actually compromised in this example.

\section{Discussion}

The on-farm data (Table 1) demonstrated the advantages of dryland lucerne compared with the dryland pasture. Stocking rate differed across the region and farming types. The lowest stocking rate of 1.2 ewes/ha was on dry foothill country on native pasture, and was lower than normal as the remaining ewes were transferred to lucerne at docking. Stocking rates on the lucerne differed in line with soil depth and available water holding capacity.

The lucerne stands had the most consistent result from year to year, with the added bonus that several paddocks were also able to be taken for hay in 2010, due to high levels of available soil moisture coming out of the winter. Kearney et al. (2010) also recorded a consistent spring lucerne growth response in the same environment until soil moisture restricted growth in late spring.

The liveweight gain in 2009 was slightly higher than 2010, highlighting the need to provide close management in years when feed supply is higher. In this wetter year, some dryland pastures did produce lamb liveweight gains similar to lucerne. This occurred from low stocking rates and high feed quality due to unusually high annual legume content.

Ewe body condition score is an important part of maintaining consistent production from season to season (Stevens et al. 2011). Flocks grazing lucerne had higher condition scores at weaning, as reported previously by Avery et al. (2008). Occasionally flocks measured on dryland pasture were similar in condition score to those on lucerne. This was a benefit of the ability to reduce dryland pasture stocking rate when lucerne was grazed. However, the range of condition scores in the ewes from pasture was greater, with more being below 2.5 and above 4.

While every farm is different, these results allow us to provide some robust outcomes that can be generally applied. Once the results are interpreted by individual farmers, then the way the results may be applied can be determined.

The use of spring grazing of lucerne on significant areas of two typical Central Otago farm types increased the profitability of both. These properties are typical of many Central Otago properties that have significant areas of dryland pasture.

Both properties increased stocking rate without increasing winter cropping requirements due to the ability to graze lucerne into the winter. Small shifts in lambing date may be required, and were modelled in the traditional merino hill model, but are offset by increased lamb growth rates and the reliability of lucerne growth in spring. Beef finishing was also profitable for utilising the added production from dryland lucerne and may provide a more flexible, lower labour option in this highly variable environment.

The practice of spraying pure lucerne stands for weeds in this environment is usually undertaken every second year. Spraying lucerne costs approximately $\$ 60 /$ ha. Done every other year, this adds approximately $\$ 4 /$ ha to the costs of the traditional merino hill and \$13/ha to the valley floor properties.

Changes in labour may be required. Beef and Lamb Economic Service (2012) data record wages paid as approximately $\$ 4 / \mathrm{su}$ for Class 6 South Island finishing breeding properties. This adds per hectare costs of $\$ 3.20$ to the traditional merino hill and $\$ 7.20$ valley floor properties. The models do not account for changing capital values, or any changes in infrastructure such as fencing or water supply which may be required to implement the addition of lucerne. Further infrastructure may not be required if lucerne is used in many paddocks on the farm. This was the case on two of the farms studied where extensive plantings of lucerne were done. Overall, the calculated increases in potential gross margin are substantial.

The modelling of the net pasture cover offered by lucerne over 10 years showed that lucerne provided a reliable feed supply for a stocking rate of 10 ewes and twin lambs per hectare in every season, even though opening cover was below optimum in 2 of the 10 years. The changes in lucerne growth were driven by temperature rather than cover in these models, suggesting that a late start to spring may carry on as a cold spring. When covers were well above what was required, there are significant opportunities to conserve surplus feed, allowing a buffer of feed to be built up to offset the potential feed deficit in other years.

When the response of lucerne to winter and summer droughts was modelled and compared with recorded pasture growth data, the greater resilience of a lucernebased system was apparent. An apparent vulnerability of lucerne to cold spring temperatures was also highlighted by this modelling. This demonstrates the sensitivity of the lucerne system to the cool spring weather recorded for the year modelled. Therefore, lucerne provides greater resilience in dry conditions, but some vulnerability if conditions in early spring are cold. This may be overcome by creating a buffer of lucerne hay or baleage from the high quality surplus that is available in 2 years out of 10 . Pasture cover is higher than in the current pasture-based system under average conditions, suggesting that the lucerne system will, on average, be more resilient than a pasture system.

The Lucerne for Lambs project has provided 
evidence of the resilience of lucerne in different grazing management systems. Evidence gathered by the Lucerne for Lambs project has provided a significant data set to enable farmers to assess the potential to shift towards grazing systems based on lucerne. Using this data and known relationships between soil moisture, temperature and lucerne growth, modelling of whole farm systems has provided an insight into the implementation of grazing systems based on lucerne in the Central Otago environment.

\section{ACKNOWLEDGEMENTS}

The authors thank Sustainable Farming Fund, PGG Wrightson Consulting, PGG Wrightson Seeds, Agricom, Seed Force and Beef + Lamb NZ for funding, Combined Rural Traders for their support in establishing this project in the local region, and the farmers for the commitment and efforts that they supplied to make the project happen.

\section{REFERENCES}

Avery, D.; Avery, F.; Ogle, G.I.; Wills, B.J.; Moot, D.J. 2008. Adapting farm systems to a drier future. Proceedings of the New Zealand Grassland Association 70: 13-18.

Beef and Lamb Economic Service, 2012. Sheep and beef farm survey: Survey data: revenue, expenditure and profit before tax - Farm data grouped by farm class. http://www.beeflambnz.com/information/onfarm-data-and-industry-production/sheep-beef-farmsurvey/. Accessed June 2012

Brash, D.W.; Beecroft, F.G. 1987. Soil resources of Central Otago. Proceedings of the New Zealand Grassland Association 48: 23-30.

Brown H.E.; Moot, D.J.; McKenzie, B.A. 2005a. Temperature responses of lucerne radiation and water use efficiency. Agronomy NZ 35: 23-32

Brown, H.E.; Moot, D.J.; Pollock, K.M. 2005b. Herbage production, persistence, nutritive characteristics and water use of perennial forages grown over 6 years on a Wakanui silt loam. New Zealand Journal of Agricultural Research 48: 423-439
Cossens, G.G. 1987. Agriculture and climate in Central Otago. Proceedings of the New Zealand Grassland Association 48: 15-21.

Cossens, G.G. 1990. Pasture and lucerne production in Otago and Southland 1950-1987. Invermay Technical Report 21, Invermay Agricultural Centre, Mosgiel, NZ. $31 \mathrm{pp}$.

Ibbotson Cooney Ltd. 2011. Farm Survey 2011. http:// www.iclca.co.nz/farm survey. Accessed June 2012

Kearney, J.K.; Moot, D.J.; Pollock, K.M. 2010. Onfarm comparison of pasture production in relation to rainfall in Central Otago. Proceedings of the New Zealand Grassland Association 72: 121-127.

Kelly 1987. Towards 2000: Farming and potential: Central Otago. Proceedings of the New Zealand Grassland Association 48: 9-14.

NIWA Virtual Climate Network. 2012. http://cliflo. niwa.co.nz/, Station 14216

Moot D.J.; Brown, H.E.; Teixeira, E.I.; Pollock, K.M. 2003. Crop growth and development affect seasonal priorities for lucerne management. Legumes for dryland pastures. Grassland Research and Practice Series 11: 201-208.

Moot, D.J; Brown, H.E.; Pollock, K.; Mills, A. 2008. Yield and water use of temperate pastures in summer dry environments. Proceedings of the New Zealand Grassland Association 70: 51-57.

Stevens, D.R.; Thompson, B.R. 2012. Lucerne for lambs whole farm modelling for two Central Otago farm systems. Report to Sustainable Farming Fund, 17pp. http://www.farmingsheep.co.nz. Accessed October 2012.

Stevens, D.R.; Casey, M.J.; Scandrett, J.S.; Baxter, G.S. 2011. Winter feeding - changing labour requirements and productivity. Proceedings of the New Zealand Grassland Association 73: 51-56 
